\title{
Impact of Domestic Industrial Output on Economic Growth in Nigeria
}

\author{
Kazeem Fasoye ${ }^{1}$, Abiodun Sunday Olayiwola ${ }^{2}$, Kehinde Elizabeth Joseph ${ }^{3}$ \\ ${ }^{1}$ Department of Economics, Obafemi Awolowo University, Ile-Ife .Nigeria. Email: \\ qosimfasoye@yahoo.com \\ ${ }^{2}$ Department of Economics, College of Arts, Management and Social Sciences, Chrisland University, \\ Abeokuta, Ogun State, Nigeria. Email: abiodunolayiwola37@gmail.com \\ ${ }^{2}$ School of Basic and Remedial Studies, Kwara State College of education, Ilorin, Nigeria. Email: \\ Callkenny_alabi@yahoo.com
}

\begin{tabular}{|c|c|}
\hline Article Info & Abstract \\
\hline Article history: & Purpose: \\
\hline $\begin{array}{l}\text { Received: } 10 \text { December } 2020 \\
\text { Revised: } 14 \text { February } 2021\end{array}$ & $\begin{array}{l}\text { This paper examined the potential of domestic industrial output on economic } \\
\text { growth in Nigeria. }\end{array}$ \\
\hline Accepted: 14 February 2021 & $\begin{array}{l}\text { Approach/ Methodology/ Design: An Autoregressive Distributed Lag (ARDL) } \\
\text { model procedure was employed for data analysis. }\end{array}$ \\
\hline $\begin{array}{l}\text { Keywords: } \\
\text { Domestic output, Capital, } \\
\text { Labour, Made-in-Nigeria, } \\
\text { Gross Domestic Product } \\
\text { (GDP) } \\
\text { JEL: O4, D2, D24 } \\
\text { Paper Type : } \\
\text { Research Article }\end{array}$ & $\begin{array}{l}\text { Findings: The results revealed that the contribution of the domestic industrial } \\
\text { output to economic growth was appalling which was necessitated by the } \\
\text { worrisome image of "Made-in-Nigeria" goods. It was also showed that the } \\
\text { results that domestic industrial output and domestic savings have positive } \\
\text { relationships with real gross domestic product (RGDP) in the long run. This } \\
\text { implies that a rise in the level of each of domestic output and domestic savings } \\
\text { necessitated an increase in real gross domestic product (RGDP). } \\
\text { Practical Implication: The implication presented in this study is related to the }\end{array}$ \\
\hline $\begin{array}{l}\text { Corresponding Author: } \\
\text { Kazeem Fasoye } \\
\text { Email: } \\
\text { qosimfasoye@yahoo.com }\end{array}$ & $\begin{array}{l}\text { concerned authorttes. The results indicate the need for diverse domestic } \\
\text { production in order to achieve a healthy competition in the industrial sector } \\
\text { in the country. } \\
\text { Originality/Value: The study innovates by employing various statistical tools } \\
\text { for exploring the effect of domestic industrial output on economic growth. The } \\
\text { significant contribution of this study is in identifying that domestic production } \\
\text { in Nigeria has been lagged behind in terms of output performance in the } \\
\text { economy. }\end{array}$ \\
\hline
\end{tabular}

\section{Introduction}

Nigeria is becoming a dumping ground for all categories of goods from all over the world (Ibrahim, 2017). This is therefore inimical to the nation's quest for sustainable development. This largest economy in Africa is worth a target in this respect despite several efforts by successive governments over the years to redress and reverse the unwholesome preference for foreign goods (Adeoye, 2015).This effort is to enhance an improved domestic output. It is worthy of note that the nation's foreign reserves are being spent on importing finished consumer products that could be sourced locally if efforts were made to patronize Nigerian products (Ibrahim, 2017). As the pressure on the naira begins to mount over the country's excessive import bills and low foreign exchange from exports, the Federal Government has intensified efforts to encourage Nigerians to buy locally made goods (Iloani, 2016).

Relevant data from the National Bureau of Statistics show that consumer confidence; business confidence, competitiveness and corruption ratings remain worrisome and affect the image of 
goods made in Nigeria. As at the fourth quarter of 2015, consumer confidence in Nigeria dropped to -3 from -1.9 per cent, while business confidence stood at $8.3 \%$ at the end of 2016 (NBS, 2016). Similarly, domestic output in Nigeria attracted significant negative attention especially on competitiveness and corruption rankings (Iloani, 2016). Also, Obadian (2014) stated that one of the most cost-effective ways to boost demand of locally manufactured goods is moral suasion, appealing to peoples' conscience to patronize local goods rather than foreign goods. Though local products have been portrayed as inferior in the past, currently they have higher chances of competing with international market players as their quality is being improved upon (Kehindeet al., 2016).

The Federal Government of Nigeria established Anchor Borrowers' Programme (ABP) in 2016 to boost local production of grains (such as rice, wheat and other agricultural products). The $\mathrm{ABP}$ was initiated as a policy option to create an ecosystem that connects small farm owners to big processors within the economy so as to improve capacity utilization and promote exports. To further enhance this trending development, an Aba-Made exhibition was initiated to showcase an array of domestic consumer goods made locally in Aba, the largest trading hub in Eastern Nigeria. The fair was an avenue of exhibiting potential in the promotion of locally-produced goods. Thus, with this feat, local manufacturers are, without doubt, on the verge of meeting up with international standard towards enhancing patronage from both local and foreign consumers.

Nigerian economy currently faces myriads of enormous economic challenges and a bleak future if fundamentally proactive steps are not taken to address the ugly situation (Ibrahim, 2017). The requirements, among others, for revamping this moribund economy are rapid and broad-based growth in the nation's domestic production. Creating the enabling environment for such growth requires a renewed motivation from the government, not minding the failed efforts of past administrations (Obioma et al., 2015). Thus, the urgency to heighten the production of Nigerian made goods was brought to bear recently when the economy slid into recession following two consecutive quarters of negative economic growth commencing from January, 2016. The economy only began to recover in June 2017, as announced by National Bureau of Statistics (Fasoye, 2018). This is characterized by reduced commodity prices owing to low productivity precipitated by the contraction of the economy. This study was motivated by the concerted effort of the Federal government to encourage not only the local production but also the patronage of Made-in-Nigeria products with the utmost aim of improving the nation's gross domestic product.

The review of related literature revealed that the benefits of domestic production in terms of revenue generation at the local, state and federal levels are yet to be fully explored (Ibrahim, 2017; Oburota \& Ifere, 2017). Moreover, encouraging greater domestic output by government has noticeable impact on the nation's economic growth as domestic consumers with disdain for some local goods tend to discourage the preference for foreign goods in the long-run.

Against this background, this study provides fresh empirical evidence on the subject matter. Though several studies have examined the nexus between local production and economic growth but the challenges of domestic production in Nigeria seem insurmountable. This paper, therefore, examined the potential of domestic industrial output on economic growth in Nigeria. 


\section{Literature Review}

A highly consuming nation is premised on real sector of the economy and an important real sector that promotes local production in Nigeria is Agricultural sector. The impact of Agricultural output on economic growth in Nigeria cannot be over-emphasized as it revealed a positive and significant relationship between gross domestic product (GDP) and agricultural output in Nigeria(Ogunsanya et al., 2017). Agricultural sector was estimated to have contributed 2.247 percent variation in gross domestic product (GDP) from 1981 to 2014 in Nigeria. The findings of the study imply that agricultural sector has contributed significantly to the variation or changes in economic activities in Nigeria.

In the same vein, Chete et al.(2015) in their study explored the evolution of the industrial sector in Nigeria (as an important real sector in the economy) over the last 50 years and submitted that over half of the gross domestic product (GDP) was accounted for by the primary sector with agriculture playing an important role. Though, oil and gas sector was also a major driver of the economy but manufacturing and industrial sectors in Nigeria accounted for a tiny proportion of economic activity. Contrary to the findings above, manufacturing output, capital and technology were portrayed as the major determinants of economic growth as industrial output was found to have contributed significantly to the economic growth in Nigeria (Oburota \& Ifere, 2017).

Emphasis on the growth of industrial output in both developed and developing economies is not adequate unless production is diversified. Therefore, the production diversity and per-capita income in North-Eastern states of India has attracted much attention in literature. The trends of the food production and consumption diversity across the states was empirically examined by Venkatesh, Sangeetha and Singh (2016) and the results of the study revealed that per capita consumption has decreased in cereals and is stagnant in pulses, and has doubled in edible oils, vegetables, eggs, fish and meat during the study period. The study has highlighted a significant impact of local production diversity on consumption pattern and by implication, policies should targeting the diversification of agricultural production, particularly in the North-Eastern states to bring out dietary diversity and desired nutritional outcome has been significantly abandoned.

The motive of diversification of local production in the economy is not only to attain the desired level of output but also to ensure healthy competition among the local industries. An investigation of market factors which influence the performance of the locally manufactured sugar from the manufacturing firms in Kenya reveal that consumption of sugar in Kenya varies from an average rate of about $2.2 \%$ whereas sales of sugar registered an average of $2.1 \%$. From the findings of the study, Obange et al.(2011) reported a market deficit of locally produced sugar that falls below market demand. The study concludes that price related factors significantly contribute to poor performance of local sugar manufacturing firms under the prevailing imperfect market conditions in Kenya.

Studies have also revealed that it is not only price-related factors but also investment, human capital, income levels, manufacturing export and industrial output have not reached the desired threshold to achieve economic growth (Dan \&Wanjuu, 2016; Joseph et al., 2019) but the 
empirical study of Aiyedogbon \& Anyanwu, (2015), which examined the macroeconomic determinants of industrial development, showed that industrial productivity itself has failed to yield the required positive result. Moreover, the effect of industrial development on economic performance was appalling which was necessitated by the intermittent electricity supply in Nigeria (Udah, 2010). The implication here is that domestic production in Nigeria has been lagged behind in terms of output performance in the economy.

The studies conclude that an improved domestic production in both developed and emerging economies will, in no small measure, enhance sustainable economic growth. The economies can only achieve a healthy competitive manufacturing hub if the emphasis is placed on local content and diverse domestic production.

\section{Methodology and Procedures}

The study is anchored on Kaldor growth theory which was published in 1957 in line with the Harrodian dynamic approach and the Keynesian techniques of analysis. The model establishes the relationship between industrial output and economic growth, which is a triangulation of Kaldor first law and the endogenous growth theory as

$$
Y=f(I N D)
$$

Where, $\mathrm{Y}$ is the real gross domestic product (proxy for economic growth) and IND is the industrial output.

\section{Model Specification}

For an economy to achieve sustained economic growth, the theory above assumes that there are only two factors of production i.e., capital and labour, thus, the entire industrial sector must be willing to invest in both human and material capital development. Labour force must be trained in the field of research and development to improve the nation's manpower. The model above is further transformed as

$$
R G D P=f(D I N, K, L)
$$

Also, the part of income that is not consumed is saving, then, in consonance with Accelerator Theory of Investment, accumulated savings (in form of capital stock) leads to increase in output; to this end, domestic savings (DS) will be incorporated as an explanatory variable. Then, equation (2) above becomes

$$
R G D P=f(D I N, K, L, D S)
$$

The equation (3) above can be expressed explicitly in an estimable form as

$$
R G D P_{t}=\alpha+\beta_{1} D I N_{t}+\beta_{2} K_{t}+\beta_{3} L_{t}+\beta_{4} D S_{t}+\mu_{t}
$$


where, RGDP is Real Gross Domestic Product, DINis Domestic industrial output, Kislevel of Capital (proxied by Gross fixed capital formation), $\mathrm{L}$ is the total Labour force and DSis the level of Domestic savings in the economy.

All the variables in equation (4) above are expressed in natural logarithmic form not only to linearise the relationship but also to remove that systematic change in spread, achieving approximate "homoscedasticity." in the model (Asteriou and Hall, 2007).Then, equation (4) becomes

$$
\ln R G D P_{t}=\alpha+\beta_{1} \ln D I N_{t}+\beta_{2} \ln K_{t}+\beta_{3} \ln L_{t}+\beta_{4} \ln D S_{t}+\mu_{t}
$$

In order to examine both the short-run and long-run effects of the explanatory variables on the explained variable in the equation (5) above, the Autoregressive Distributed Lag (ARDL) model procedure developed by Pesaran, Shin and Smith (2001) attempts to capture the relationship in $f(D I N, K, L, D S)$.. The advantage of ARDL over other estimation techniques is that it yields consistent estimates of the parameters when the variables are all integrated at levels i.e. $\mathrm{I}(0)$ or integrated at first difference i.e. I(1) or an admixture of both, then, long run relationship exists (Pesaran, Shin and Smith, 2001).

Therefore, the Autoregressive Distributed Lags (ARDL) model is written as:

$$
\begin{aligned}
\Delta \ln R G D P_{t}= & \alpha_{o}+\sum_{i=1}^{p} \delta_{i} \Delta \ln R G D P_{t-1}+\sum_{i=1}^{p} \gamma_{i} \Delta \ln D I N_{t-1}+\sum_{i=1}^{p} \theta_{i} \Delta \ln K_{t-1}+\sum_{i=1}^{p} \sigma_{i} \Delta \ln L_{t-1} \\
& +\sum_{i=1}^{p} \emptyset_{i} \Delta \ln D S_{t-1}+\omega_{1} \ln R G D P_{t-1}+\omega_{2} \ln D I N_{t-1}+\omega_{3} \ln K_{t-1}+\omega_{4} \ln L_{t-1} \\
& +\omega_{5} \ln D S_{t-1}+\mu_{t}
\end{aligned}
$$

Where $\alpha_{o}$ is the drift component of the model; $\mu_{t}$ is the stochastic error term; the terms with summation signs $\sum_{i=1}^{p}$ represents the error correction dynamics while the second part of the equation with $\omega_{i}$ is the long run relationship of the model. In order to estimate the short-run relationship between the variables, the corresponding error correction equation was estimated as:

$$
\begin{aligned}
\Delta \ln R G D P_{t}= & \alpha_{o}+\sum_{i=1}^{p} \delta_{i} \Delta \ln R G D P_{t-1}+\sum_{i=1}^{p} \gamma_{i} \Delta \ln D I N_{t-1}+\sum_{i=1}^{p} \theta_{i} \Delta \ln K_{t-1}+\sum_{i=1}^{p} \sigma_{i} \Delta \ln L_{t-1} \\
& +\sum_{i=1}^{p} \emptyset_{i} \Delta \ln D S_{t-1}+\omega_{i} E_{C} M_{1 t-1}+\mu_{t}
\end{aligned}
$$

The $E C M_{1 t-1}$ is the Error Correction Model for the equation (7) above.

Thus, the ECM version of ARDL was applied to determine the speed of adjustment to equilibrium. The purpose here is to estimate the coefficients of the long run relationship, followed by the estimation of the short run elasticity of the variables. 


\section{Results and Discussion}

\section{Tests for Stationarity}

To confirm the stationarity or otherwise of the variables, the following hypotheses were tested:

$$
\begin{aligned}
& H_{0}: \boldsymbol{\alpha}=0\{\text { variables are non-stationary }\} \\
& H_{1}: \boldsymbol{\alpha}<0\{\text { variables are stationary }
\end{aligned}
$$

Therefore, for the series to be stationary, the following conditions must hold: $\boldsymbol{\alpha}<0$ and $\boldsymbol{\rho}<$ 0 , if otherwise, the variables are non-stationary because the test may be biased which may call for further test of biased Rho-1( i.e. $\left.\rho^{*}-1\right)$.

\begin{tabular}{|c|c|c|c|}
\hline \multirow{2}{*}{\multicolumn{4}{|c|}{\begin{tabular}{|l|} 
Variables: DIN DS K L RGDP \\
Method: Phillips-Ouliaris Test Equation
\end{tabular}}} \\
\hline & & & \\
\hline & $\operatorname{Value}(\alpha)$ & Prob. & $\begin{array}{l}\text { Rho }-1 \\
(\rho-1)\end{array}$ \\
\hline Phillips-Ouliaris tau-statistic & -4.497569 & 0.00098 & -1.937523 \\
\hline Phillips-Ouliaris z-statistic & -19.54769 & 0.0290 & -1.937523 \\
\hline
\end{tabular}

Table 1: Stationarity Test results

Source: Authors' computation from the data extracted from CBN statistical bulletin and World

Development Indicators (1990 - 2018)

From the Table 1 above, since $\boldsymbol{\alpha}<0$ (i.e. $\boldsymbol{\alpha}=-4.497569$ and-19.54769) and $\boldsymbol{\rho}-\boldsymbol{1}=--$ 1.937523 (which implies that $\boldsymbol{\rho}<0$ ). Thus, the conditions for stationarity are met and the results indicate that the variables are stationary around deterministic linear trend and they are all statistically significant at $5 \%$.

Based on Phillips-Ouliaris stationarity test results in Table 1, the null hypothesis that variables are non-stationary at $5 \%$ level of significance for the model specifications is thus rejected.

\section{Johansen Cointegration Test}

Following the results in the Table 1 which revealed that all the variables are stationary either at levels or at first difference and at different levels of significance, there is the need to determine the long-run relationship among the variables. To achieve this, Johansen cointegration test was employed to determine the existence of long-run relationship among real gross domestic product, domestic industrial output, level of capital, total labour force and level of domestic savings in Nigeria between 1990 and 2018. It was evidenced from the Johansen cointegration test results in the Tables $2 \mathrm{a}$ and $2 \mathrm{~b}$ that the null hypothesis of no cointegration among the variables at $5 \%$ level of significance for the model specification was rejected.

The truce statistics revealed that there are cointegrating relationships among the variables as five cointegrating equations were found to exist at the $5 \%$ level of significance. Similarly, the 
unrestricted cointegration Max-Eigen value statistic reports that there exists one cointegration equation at $5 \%$ level of significance. This implies that the variables have long-run relationship.

Table2a: Johansen Cointegration Test Results: Unrestricted Cointegration Rank Test (Trace)

\begin{tabular}{|c|c|c|c|c|}
\hline $\begin{array}{c}\text { Hypothesised } \\
\text { No of CE(s) }\end{array}$ & Eigenvalue & Trace statistic & $\begin{array}{c}\text { 5\% critical } \\
\text { value }\end{array}$ & Prob** $^{* *}$ \\
\hline None $*$ & 0.827272 & 108.5348 & 69.81889 & 0.0000 \\
\hline At most 1 $*$ & 0.588580 & 61.12189 & 47.85613 & 0.0018 \\
\hline At most 2 $*$ & 0.536737 & 37.14207 & 29.79707 & 0.0060 \\
\hline At most 3 $*$ & 0.332421 & 16.36664 & 15.49471 & 0.0369 \\
\hline At most 4 & 0.182966 & 5.456010 & 3.841466 & 0.0195 \\
\hline
\end{tabular}

Source: Authors' computation from the data extracted from CBN statistical bulletin and World Development Indicators (1990 - 2018)

NOTE:_Trace test indicates 5 cointegratingeqn(s) at the 0.05 level

* denotes rejection of the hypothesis at the 0.05 level

**MacKinnon-Haug-Michelis (1999) p-values

Table 2b: Johansen Cointegration Test Results: Unrestricted Cointegration Rank Test (Maximum Eigen value)

\begin{tabular}{|c|c|c|c|c|}
\hline $\begin{array}{c}\text { Hypothesised } \\
\text { No of CE(s) }\end{array}$ & Eigenvalue & $\begin{array}{c}\text { Max-Eigen } \\
\text { statistic }\end{array}$ & $\begin{array}{c}\text { 5\% critical } \\
\text { value }\end{array}$ & Prob*** $^{* *}$ \\
\hline None $*$ & 0.827272 & 47.41296 & 33.87687 & 0.0007 \\
\hline At most 1 & 0.588580 & 23.97982 & 27.58434 & 0.1354 \\
\hline At most 2 & 0.536737 & 20.77543 & 21.13162 & 0.0560 \\
\hline At most 3 & 0.332421 & 10.91063 & 14.26460 & 0.1587 \\
\hline At most 4 & 0.182966 & 5.456010 & 3.841466 & 0.0195 \\
\hline
\end{tabular}

Source: Authors' computation from the data extracted from CBN statistical bulletin and World Development Indicators (1990 - 2018)

NOTE:

Max-eigenvalue test indicates 1 cointegratingeqn(s) at the 0.05 level

* denotes rejection of the hypothesis at the 0.05 level

**MacKinnon-Haug-Michelis (1999) p-values

\section{Bounds Test}

Since the basic tests of the model passed all the required diagnostics tests, then the next level of analysis which is Bounds test for cointegration following Pesaran, Shin and Smith (2001) was conducted. Here, the author developed the critical values of the F-statistic for the asymptotic distribution.

Table 3:Bounds Test for Cointegration Results

\begin{tabular}{|l|c|c|}
\hline F- Statistics & 17.7281 & \\
\hline Number of independent variables $-k$ & 4 & \\
\hline Critical values & Lower bound & Upper bound \\
\hline $1 \%$ & 3.74 & 5.06 \\
\hline $2.5 \%$ & 3.25 & 4.49 \\
\hline
\end{tabular}




\begin{tabular}{|l|l|l|}
\hline $5 \%$ & 2.86 & 4.01 \\
\hline $10 \%$ & 2.45 & 3.52 \\
\hline
\end{tabular}

Source: Authors' computation from the data extracted from CBN statistical bulletin and World

Development Indicators (1990 - 2018)

The results of ARDL bounds test revealed that F-test is 17.7281. The value of the estimated Fstatistic of the model has exceeded the upper bound at the $1 \%$ level of significance. It is apparent from the results that there exists long-run relationship among the variables. This implies that the series are related and can be combined in a linear fashion, even if there are shocks in the shortrun, which may affect the movement in the individual series, they would converge with time (in the long-run). Therefore, both the long-run and short-run models were estimated.

\section{Long-Run Dynamics}

The long-run equilibrium relationship between the variables using the ARDL model $(1,0,1,0$, $1,0,0)$ was estimated. The results of the long run estimation are summarized in the Table 4 below.

Table 4: Estimated long-run coefficients in ARDL

\begin{tabular}{|c|r|r|r|r|}
\hline \multicolumn{5}{|l|}{ Dependent Variable: RGDP } \\
\hline Method: Autoregressive Distributed Lags (ARDL) & \multicolumn{1}{l|}{ Prob. } \\
\hline Variables & Coefficient & Std. Error & \multicolumn{1}{c|}{ t-Statistics } & 0.4344 \\
\hline $\operatorname{lnDIN}$ & 0.137456 & 0.172778 & 0.795563 & 0.2945 \\
\hline $\operatorname{lnDS}$ & 0.350857 & 0.327023 & 1.072883 & 0.5320 \\
\hline $\operatorname{lnK}$ & -0.307294 & 0.484266 & -0.634556 & 0.0288 \\
\hline $\ln L$ & 0.457929 & 0.196339 & 2.332337 & \\
\hline
\end{tabular}

Source: Authors' computation from the data extracted from CBN statistical bulletin and World Development Indicators (1990 - 2018)

The results revealed that the coefficient of the total labour force (L) only appeared to be statistically significant while domestic industrial output (DIN), level of capital (K) and level of domestic savings (DS) in the economy have insignificant relationship with Real Gross Domestic Product (RGDP).

It was also showed from the results that domestic industrial output and domestic savings have positive relationships with real gross domestic product (RGDP) in the long run. This implies that a rise in the level of each of domestic output and domestic savings necessitated an increase in real gross domestic product (RGDP). The resulted supported the findings of Ogunsanya, Jelilov and Ozden (2017) which showed that positive relationship was found to exist between gross domestic product (GDP) and agricultural output in Nigeria.

Similarly, total labour force in the economy maintained both positive and significant relationship with real gross domestic product in the long run. This implies that Nigerian economic growth was accounted for by significant growth rate of work force. This is against the findings of Dan and Wanjuu (2016) that not only price related factors but also human capital, income levels and industrial output have not reached the desired threshold to achieve economic growth. Level of 
capital in the economy was found to have negative relationship with economic growth. By implication, it means that available capital stock has not been judiciously utilised to achieve the desired economic growth. This was in line with the findings of Oburota and Ifere, (2017) which revealed that manufacturing output, capital and technology were the major determinants of economic growth in Nigeria.

\section{Short-Run Analysis}

After explaining the long run relationship of the variables, the short-run causality in the ARDL model $(1,0,1,0,1,0,0)$ was estimated in the Table 5 below.

Table 5: Short-Run estimation from ECM

\begin{tabular}{|c|r|r|r|r|}
\hline \multicolumn{5}{|l|}{ Dependent Variable: RGDP } \\
\hline Method: Autoregressive Distributed Lags (ARDL) \\
\hline Variables & Coefficient & Std. Error & t-Statistics & \multicolumn{1}{c|}{ Prob. } \\
\hline $\mathrm{D}(\operatorname{lnDIN})$ & 0.027005 & 0.026840 & 1.006157 & 0.3248 \\
\hline $\mathrm{D}(\operatorname{lnDS})$ & 0.068932 & 0.051276 & 1.344321 & 0.1920 \\
\hline $\mathrm{D}(\operatorname{lnK})$ & -0.060373 & 0.110521 & -0.546257 & 0.5901 \\
\hline $\mathrm{D}(\operatorname{lnL})$ & 0.089968 & 0.081144 & 1.108751 & 0.0279 \\
\hline CointEq(-1) & -0.196467 & 0.111866 & -1.756272 & 0.0924 \\
\hline
\end{tabular}

Source: Authors' computation from the data extracted from CBN statistical bulletin and World Development Indicators (1990 - 2018)

Similar to the long-run analysis, results in Table 4.5 also revealed that the coefficient of the total labour force (L) only appeared to be statistically significant while domestic industrial output (DIN), level of capital (K) and level of domestic savings (DS) in the economy have insignificant relationship with Real Gross Domestic Product (RGDP).

It was also indicated from the results that all the variables (with the exception of capital) have positive impacts on Real Gross Domestic Product (RGDP) in the short-run which were confirmed by the signs and statistical significance of their coefficients. On the contrary, level of capital was found to have negative impacts on the Real Gross Domestic Product (RGDP) in the short-run. The results of the short-run analysis revealed similar behaviour of the variables with that long-run dynamics during the study period. The sign of lagged error correction term \{CointEq (-1)\} was negative and statistically significant at $10 \%$ level. Also, the value of ECM coefficient is -0.196 which signifies the extent to which any disequilibrium in the lagged error correction term affects any resulting adjustment in domestic industrial output. It is the feedback or adjustment effect which shows that $19.6 \%$ of the disequilibrium converges back to the longterm equilibrium. This implies that there is long run stability in the domestic output growth after the initial shock due to short run fluctuation. Thus, confirming the adequacy and statistically efficiency of the model.

The findings of this paper indicate that the contribution of the domestic industrial output to economic growth in Nigeria was appalling as shown by the insignificant relationship between domestic industrial output and GDP both in the sort-un and the long-run. The findings 
contradict the empirical work of (Ogunsanya et al., 2017) which revealed a positive and significant relationship between gross domestic product (GDP) and agricultural output in Nigeria. The results are also not in line with the work of Aiyedogbon \& Anyanwu, (2015), showed that industrial productivity itself has failed to yield the required positive result.

\section{Conclusion and Suggestion}

The results revealed that domestic industrial output did not have significant impact on economic growth in Nigeria both in the long-run and the short-run. It is thus concluded that the contribution of the domestic industrial output to economic growth was appalling which was necessitated by the worrisome image of goods made in Nigeria. The implication here is that domestic production in Nigeria has been lagged behind in terms of output performance in the economy. It is, therefore, recommended that emphasis should be placed on local content and diverse domestic production in order to achieve a healthy competition in the industrial sector.

\section{Conflict of Interest}

The authors declare no conflict of interest

\section{Funding}

None

\section{References}

Adeoye, B. W. (2015).“ Industrial Development in Nigeria in the Context of Globalization:

The Challenge of Industrialization: A Pathway to Nigeria Becoming a Highly Industrialized Country in the Year 2015”.Nigerian Economic Society, Ibadan, pp. 275303.

Aiyedogbon J.O. and Anyanwu, S. (2015). 'Macroeconomic Determinants of Industrial Development in Nigeria".Nile Journal of Business and Economics, 1(5): 37-46.

Asteriou, D. and Hall, S. G. (2007).“Applied Econometrics: A Modern Approach Using E-views and Micosoft."Palgrave Macmillan, (revised edition):17 - 18.

Chete, L. N.; Adeoti, J. O.; Adeyinka, F. M. and Ogundele, O. (2015).“Industrial Development and Growth in Nigeria: Lessons and Challenges".Nigerian Institute of Social and Economic Research (NISER), Ibadan, African Development Bank Group.Working Paper No.8.

Fasoye, K. (2018). "Welfare Loss and Surge in Food Commodity Prices in Nigeria”. Journal of Economics and Sustainable Development.9(15): 57 - 63.

Ibrahim, B. G. (2017). "Conceptual Models on the Economic Benefits of Made-In- Nigeria Products Procurement and the Impact of Regulatory Agencies: Analysis of Literatures." Public Procurement Journal, Bureau of Public Procurement (BPP), Issue No 5: 9 - 15.

Iloani, A. F. (2016). "Why Made-in-Nigeria Goods Suffer Low Patronage". International Marketing Review,6(1), 47-58. 
Joseph, K. E, Olayiwola, A.SandYinusa, D.O (2019).Capital Inflows, Manufacturing Exports and Economic Growth in Nigeria: A Threshold Regression Analysis. Journal of Economics and International Finance.Vol.11(5), 52-59, 2019.

Kehinde, O. J.Adegbuyi, O.,Akinbode, M. and Borishade, T. (2016)."Marketing Concept and The Satisfaction of Consumer Needs: The Nigerian Consumers' Experience".ResearchJournal of Marketing, 4(1): 348-357.

National Bureau of Statistics (2016). "Consumer Confidence Index".www.nigerianstat.gov.ng Obadian, T. (2014). "Nigerian Economy at The Crossroads". African Recovery,13(1):8.

Obange, N.,Onyango, G. M. andSiringi, E. M. (2011). "Determinants of Sugar Market Performance under Imperfect Market Conditions: Empirical Evidence from Kenya". An International Multi-Disciplinary Journal, Ethiopia, Vol. 5 (1), Serial No.18,1 - 16.

Obioma, B. K., Anyanwu, U. N. and Kalu, A. O. U. (2015). "The Effect of Industrial Development on Economic Growth: An Empirical Evidence in Nigeria 1973-2013" European Journal of Business and Social Sciences, 4(2):127 - 140.

Oburota, C. S. and Ifere, E. O. (2017)."Manufacturing Subsector and Economic Growth inNigeria" British Journal of Economics, Management \& Trade, 17(3): 1-9.

Ogunsanya, O. O.,Jelilov, G. and Ozden, K. (2017)."Empirical Study of Agriculture on EconomicGrowth:The Case of Nigeria." The Empirical Economics Letters, 16(2): 67.

Pesaran, M. H. and Shin, Y. (1998). "An Autoregressive Distributed Lag Modelling Approach to Cointegration Analysis". Econometric Society Monographs, 31: 371 - 413.

Pesaran, M. H., Shin, Y. and Smith, R. J. (2001)."Bounds Testing Approaches to the Analysis of Level Relationships".Journal of Applied Econometrics, 16(3): 289 - 326.

Udah, E.B. (2010). "Industrial Development, Electricity Crisis and Economic Performance in Nigeria".European Journal of Economics, Finance and Administrative Sciences, 2(18):1450 -2887.

Venkatesh, P. Sangeetha, V. and Singh, P.(2016). "Relationship between Food Production and Consumption Diversity in India - Empirical Evidences from Cross Section Analysis”.Agricultural Economics Research Review Vol. 29, 139-148. 